\title{
Atypical Chemokine Receptor 1 Polymorphism can not Affect Susceptibility to Hepatitis C Virus
}

\author{
Shu-Ting Zhang1, Ming Shi², Lin-Nan Shao1, Shi-Hang Zhou1, Wei-Jian Yu1, Mei Chen1, Nan Xiao1,
} Ying Duan1, Ling-Zi Pan1, Ni Wang1, Wen-Qian Song1, Yue-Xin Xia1, Li Zhang1, Ning Qi1, Ming Liu³

\author{
${ }^{1}$ Dalian Blood Center, Liaoning, China \\ ${ }^{2}$ Dalian University School of Medicine, Liaoning, China \\ ${ }^{3}$ Department of Cell Biology, Dalian Medical University, Liaoning, China
}

Background: Hepatitis $\mathrm{C}$ virus has infected 130 to 150 million individuals globally. Atypical chemokine receptor 1 has become a focus of research because of its diverse roles in different diseases. However, little is known regarding the association of atypical chemokine receptor 1 polymorphism with susceptibility to hepatitis $\mathrm{C}$ virus.

Aims: To determine the association of an atypical chemokine receptor 1 polymorphism (rs12075) with hepatitis $C$ virus susceptibility.

Study Design: Case-control study.

Methods: We collected blood samples from 231 patients infected with hepatitis $\mathrm{C}$ virus and 239 blood donors as control subjects. Genotyping of atypical chemokine receptor 1 was performed using a 5 '-nuclease assay with TaqMan-minor groove binding probes. Comparisons between hepatitis $\mathrm{C}$ virus-infected patients and control subjects were assessed using Fisher's exact test.
Results: The genotype frequencies of $F Y^{*} A / F Y^{*} A$, $F Y^{*} A / F Y^{*} B$ and $F Y^{*} B / F Y^{*} B$ were $86.1 \%, 13.9 \%$ and $0 \%$ in the patient group, and $86.2 \%, 13.4 \%$ and $0.4 \%$ in the control group, respectively. The difference in atypical chemokine receptor 1 genotype frequencies between hepatitis $\mathrm{C}$ virus-infected patients and control group was not significant $(\mathrm{p}=1.00, \mathrm{OR}=1.004,95 \% \mathrm{CI}=0.594$ 1.695). $F Y^{*} A$ and $F Y^{*} B$ allele frequencies were $93.1 \%$ and $6.9 \%$ in the patient group, and $92.9 \%$ and $7.1 \%$ in the control group, respectively. The difference in atypical chemokine receptor 1 allele frequencies between hepatitis $\mathrm{C}$ virus-infected patients and the control group was not significant $(\mathrm{p}=1.00, \mathrm{OR}=0.972,95 \% \mathrm{CI}=0.589$ 1.603).

Conclusion: Our result indicates that atypical chemokine receptor 1 polymorphism (rs12075) does not affect susceptibility to hepatitis $C$ virus.

Keywords: Atypical chemokine receptor 1, polymorphism, hepatitis $C$ virus, susceptibility

\footnotetext{
Address for Correspondence: Dr. Ming Liu, Department of Cell Biology, Dalian Medical University, Liaoning, China

Phone: +86-411-86110318ｅ-mail: liuminglinxi@163.com

Received: 16 July $2016 \quad$ Accepted: 19 January 2017 •DOI: 10.4274/balkanmedj.2016.0766

Available at www.balkanmedicaljournal.org
}

Cite this article as:

Zhang ST, Shi M, Shao LN, Zhou SH, Yu WJ, Chen M. et al, Atypical Chemokine Receptor 1 Polymorphism can not Affect Susceptibility to Hepatitis C Virus. Balkan Med J 2017;34:308-12

${ }^{\circ}$ Copyright 2017 by Trakya University Faculty of Medicine / The Balkan Medical Journal published by Galenos Publishing House. 
A global public health problem in both developing and developed countries, hepatitis $\mathrm{C}$ virus (HCV) has infected 130 to 150 million individuals globally according to the World Health Organisation. The annual increase of HCV infection is approximately 3.5 million (1). A significant number of those who are chronically infected will develop liver cirrhosis, hepatocellular cancer and liver failure (2), and more than $70 \%$ of patients with $\mathrm{HCV}$ infection develop chronic infections leading to end-stage liver diseases or even death (3). Only $15-45 \%$ of infected patients successfully eliminate the virus spontaneously. In Asia, more than 100 million individuals may be chronically infected with HCV (4). Recent data suggest that the prevalence of $\mathrm{HCV}$ infection ranges from $0.43 \%$ to $3.2 \%$ in the Chinese population, and varies geographically and temporally in China (5). HCV is a blood borne virus and the major modes of transmission are through inadequate sterilisation of medical equipment, unsafe injection practices, sexual contact and unscreened blood or blood product transfusion.

The Duffy blood group antigens, recently renamed atypical chemokine receptor 1 (ACKR1) (6), are glycoproteins expressed mainly in erythrocytes, in endothelial cells throughout the body, and in cerebellar neurons (7). The Duffy gene is situated on chromosome 1 at the q22-q23 position. Three main alleles have been characterised: $F Y^{*} A$ (encoding Fya), $F Y^{*} B$ (encoding $\mathrm{Fy}^{\mathrm{b}}$ ), and $F Y^{*} B E S$ (8). $F Y^{*} A$ and $F Y^{*} B$ are differentiated by a single nucleotide polymorphism (SNP), rs12075 (9). $F Y^{*} B E S$ corresponding to the Fy (a-b-) phenotype and a lack of ACKR1 in erythrocytes, is disrupted by a SNP, rs2814778 (T-33C) in the GATA box motif of the gene's promoter region (10). The phenotype of Fy (a-b-) is present in most West Africans (>95\%) and in approximately $68 \%$ of African American individuals, but is rare in the Chinese population (11).

ACKR1 is responsible for interactions with chemokines (12). Moreover, ACKR1 has also been described as a chemokine "sink" to bind and clear chemokines from sites of overproduction (13). There is abundant evidence to suggest that ACKR1 polymorphisms are associated with some diseases, such as chronic periodontitis, breast cancer and Plasmodium vivax malaria (14-16). Several studies have demonstrated that the erythrocyte complement receptor is associated with HCV (17-19). Moreover, as another receptor on erythrocytes, ACKR1 polymorphism may play a critical role in human immunodeficiency virus (HIV) infection $(20,21)$. However, little is known regarding the association of ACKR1 polymorphism with susceptibility to $\mathrm{HCV}$.

In this study, we investigate the association of ACKR1 polymorphism (rs12075) with susceptibility to HCV. If rs12075 is a risk factor, exploring this specific indicator in patients with $\mathrm{HCV}$ infection could benefit the development of novel strategies to detect and prevent infection at the early stage.

\section{MATERIALS AND METHODS}

\section{Patients and samples}

A total of $231 \mathrm{HCV}$-infected patients who were in treatment in Dalian infectious hospital were recruited to participate in this study, and 239 unrelated healthy blood donors were recruited as a control group. To avoid sampling error and inter-observer variation, and to avoid introducing bias, patients with $\mathrm{HCV}$ infection were recruited according to the following criteria: presence of HCV antibody and HCV RNA with abnormal liver function tests and/or biopsy evidence of $\mathrm{HCV}$ related liver diseases. Ethics committee approval was received for this study from the local ethics committee. Written informed consent was obtained from all participants in the study.

The whole peripheral blood specimens were collected in vacuum tubes with EDTA as anticoagulant. DNA was extracted from peripheral lymphocytes using a DNA isolation kit (RBCBioscience, Taipei, Taiwan) following the manufacturer's instructions.

\section{ACKR1 genotyping}

ACKR1 was genotyped using a 5'-nuclease assay (NA) with TaqMan minor groove binding (MGB) probes. The primers and probes were synthesised by Applied Biosystems (Table 1). The polymerase chain reaction (PCR) mixtures included $1 \mu \mathrm{L}$ of purified genomic DNA, $10 \mu \mathrm{L}$ of 2x TaqMan Universal PCR Master Mix (Applied Biosystems, Foster City, CA, USA), 0.9 $\mu \mathrm{L}$ of each primer $(20 \mu \mathrm{M}), 0.2 \mu \mathrm{L}$ of each probe $(20 \mu \mathrm{M})$ and $6.8 \mu \mathrm{L}$ of distilled water in a final reaction volume of $20 \mu \mathrm{L}$. The 5'-NA was performed on an ABI Prism 7300 sequence detection system (Applied Biosystems) using a cycle of $95{ }^{\circ} \mathrm{C}$ for $10 \mathrm{~min}$, followed by 40 cycles at $95^{\circ} \mathrm{C}$ for $15 \mathrm{~s}$ and $60^{\circ} \mathrm{C}$ for $1 \mathrm{~min}$. The results were sorted into three distinct groups, corresponding to the three genotypes, homozygous $F Y^{*} A$ / $F Y^{*} A, F Y^{*} B / F Y^{*} B$ and heterozygous $F Y^{*} A / F Y^{*} B$.

\section{Statistical analysis}

Fisher's exact tests and Mann-Whitney U-tests were used for comparisons based on gender and age, respectively. Allele frequencies and genotype frequencies were obtained by the

TABLE 1. Primers and TaqMan-MGB probe sequences

\begin{tabular}{lcc}
\hline Primers and probes & Sequence $\left(5^{\prime}-3^{\prime}\right)$ & Tm $\left({ }^{\circ} \mathrm{C}\right)$ \\
\hline Forward primer & TGTGAATGATTCCTTCCCAGATG & 59.8 \\
Reverse primer & CACTGGTGAGGATGAAGAAGGG & 59.6 \\
Probe for FY*A & FAM-AGACTATGGTGCCAAC-MGB & 65 \\
Probe for FY*B & VIC-AGACTATGATGCCAACC-MGB & 66 \\
\hline $\begin{array}{l}\text { The polymorphic sites are underlined, Tm: melting temperature; MGB: minor groove } \\
\text { binding }\end{array}$ & \\
\hline
\end{tabular}


direct counting method. To evaluate the distribution of gene frequencies in two groups, the classical test for Hardy-Weinberg equilibrium (HWE) was examined. Comparisons between HCVinfected patients and the control group were assessed using Fisher's exact test. P values $<0.05$ were considered statistically significant. The strength of the relationship was estimated by calculating the odds ratios (OR) and $95 \%$ confidence intervals (CI).

\section{RESULTS}

Overall, 231 patients with HCV infection and 239 healthy individuals were genotyped by using the TaqMan-MGB probes. Representative analysis results are presented in Figure 1. No significant deviation was found from HWE within each group ( $p=0.26$ in HCV-infected patients; $p=0.84$ in the control group). Table 2 summarises the ACKR1 genotype and allele frequencies in the patient and control groups. The genotype frequencies of $F Y^{*} A / F Y^{*} A, F Y^{*} A / F Y^{*} B$ and $F Y^{*} B / F Y^{*} B$ were $86.1 \%, 13.9 \%$ and $0 \%$ in the patient group, and $86.2 \%, 13.4 \%$ and $0.4 \%$ in the control group, respectively. The difference in ACKR1 genotype frequencies between $\mathrm{HCV}$-infected patients and the control group was not significant $(\mathrm{p}=1.00, \mathrm{OR}=1.004,95 \% \mathrm{CI}=0.594$ -
1.695). Moreover, $F Y^{*} A$ and $F Y^{*} B$ allele frequencies were $93.1 \%$ and $6.9 \%$ in the patient group, and $92.9 \%$ and $7.1 \%$ in the control group, respectively. The difference in ACKR1 allele

TABLE 2. The distributions of the ACKR1 genotypes and alleles in hepatitis $\mathrm{C}$ virus-infected patients $(\mathrm{n}=231)$ and the control group $(\mathrm{n}=239)$

\begin{tabular}{|c|c|c|c|c|}
\hline & Patients & Controls & p-value & OR $(95 \% \mathrm{CI})$ \\
\hline \multicolumn{5}{|l|}{ Gender } \\
\hline Male/female & $122 / 109$ & $147 / 92$ & 0.062 & \\
\hline \multicolumn{5}{|l|}{ Age } \\
\hline $\begin{array}{l}\text { Medians } \\
\text { (interquartile range) }\end{array}$ & $\begin{array}{c}45 \\
(36 \sim 53)\end{array}$ & $\begin{array}{c}44 \\
(34 \sim 50)\end{array}$ & 0.083 & \\
\hline \multicolumn{5}{|l|}{ Genotype } \\
\hline$F Y^{*} A / F Y^{*} A$ & 199 & 206 & & 1 \\
\hline$F Y^{*} B / F Y^{*} B$ & 0 & 1 & 1.00 & $\begin{array}{c}1.004 \\
(0.594-1.695)^{*}\end{array}$ \\
\hline$F Y^{*} A / F Y^{*} B$ & 32 & 32 & & \\
\hline \multicolumn{5}{|l|}{ Allele } \\
\hline$F Y^{*} A$ & 430 & 444 & \multirow{2}{*}{1.00} & 1 \\
\hline$F Y^{*} B$ & 32 & 34 & & $\begin{array}{c}0.972 \\
(0.589-1.603)\end{array}$ \\
\hline$F Y^{*} A / F Y^{*} A$ vs. $\left(F Y^{*} A / F Y^{*}\right.$ & $+F Y^{*} B / F$ & B), OR: odd & tio; CI: cc & fidence interval \\
\hline
\end{tabular}
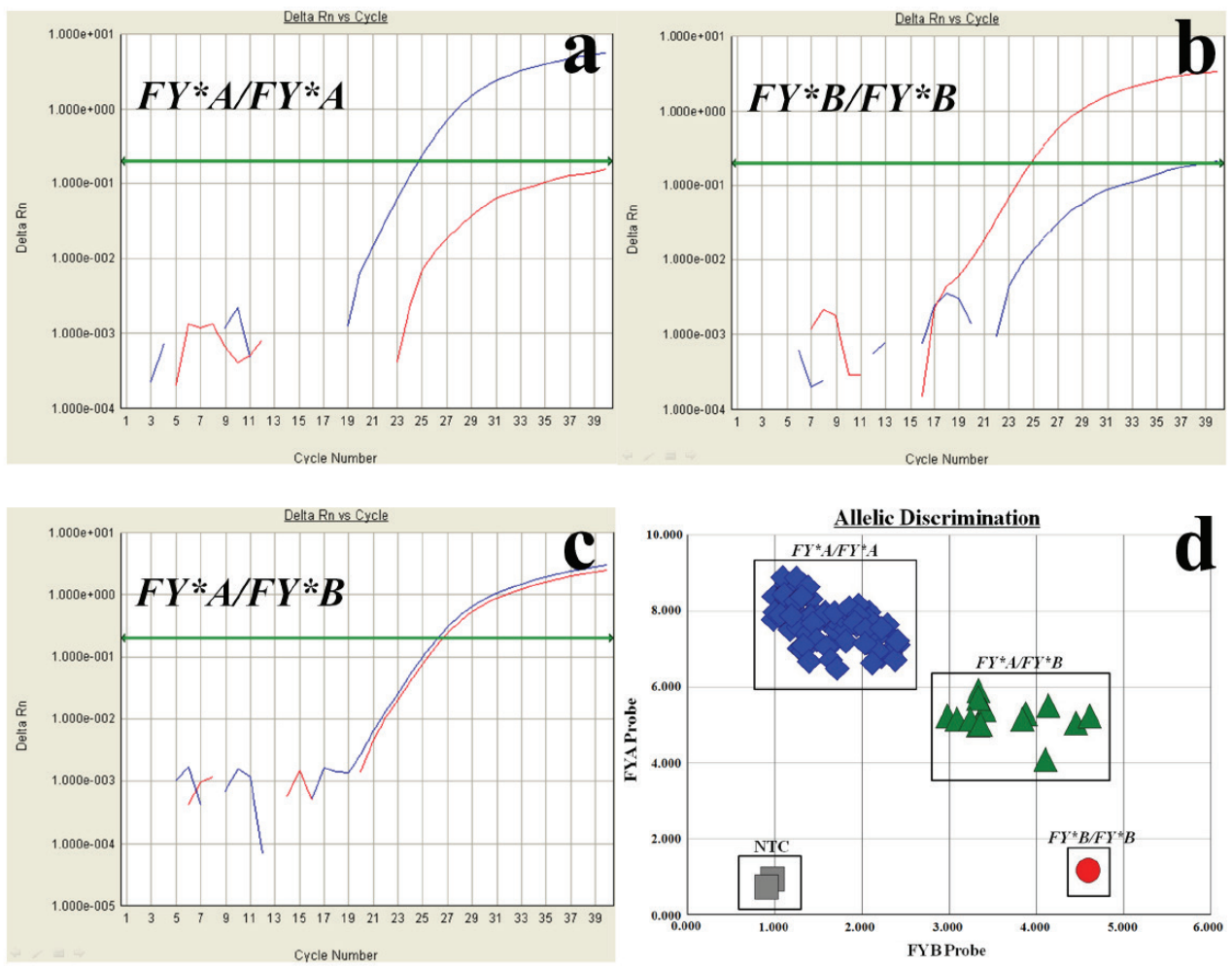

FIG. 1. a-d. Representative amplification curves of homozygous $F Y^{*} A / F Y^{*} A$ (a), homozygous $F Y^{*} B / F Y^{*} B$ (b) and heterozygous $F Y^{*} A / F Y^{*} B(c)$. End-point fluorescent signals from several samples (d) Homozygous $F Y^{*} A / F Y^{*} A$ showed an increased fluorescence along the $Y$-axis, homozygous $F Y^{*} B / F Y^{*} B$ along the $X$-axis, whereas heterozygous $F Y^{*} A / F Y^{*} B$ showed an increase in fluorescence intensity along both the $X$-axis and the $Y$-axis. Blue curves: fluorescent intensity of dye FAM. Red curves: fluorescent intensity of dye VIC. NTC: No Template Control. 
frequencies between $\mathrm{HCV}$-infected patients and the control group was not significant $(\mathrm{p}=1.00, \mathrm{OR}=0.972,95 \% \mathrm{CI}=0.589$ 1.603).

\section{DISCUSSION}

ACKR1 was identified as a blood group antigen that was expressed on the human red blood cell surface in 1950 (22). In the early 1990s, ACKR1 was found to be a receptor for interleukin 8 and other inflammatory chemokines $(13,23)$. In recent years, ACKR1 SNPs have become the focus because of their complex and critical roles in diseases. Yang et al. (16) suggested that ACKR1 polymorphism could affect metastasis of breast cancer and the $F Y^{*} B$ allele could decrease the possibility of lymph node metastasis. He et al. (20) found that ACKR1 polymorphism was associated with a $40 \%$ increase in the odds of acquiring HIV-1. King et al. (14) demonstrated that ACKR1 polymorphism affected binding of Plasmodium vivax Duffy binding protein to erythrocytes and $\mathrm{FY}^{*} \mathrm{~A}$ was associated with a lower risk of clinical Plasmodium vivax in humans compared with $F Y^{*} B$.

In the present study, we detected the polymorphism (rs12075) of ACKR1 in 231 patients with HCV infection and 239 healthy individuals. The results showed in both the HCV-infected patients and in the control group, the $F Y^{*} A$ allele and $F Y^{*} A$ / $F Y^{*} A$ genotype were absolutely predominant, while $F Y^{*} B$ / $F Y^{*} B$ was rare. These results were in good accordance with the distribution of the allelic groups found around the world (11). Our study was based on the hypothesis that ACKR1 polymorphism, which can affect HIV susceptibility, might also be associated with HCV infection. We here tested the hypothesis that this genetic variant (rs12075) in ACKR1 is a risk factor for $\mathrm{HCV}$ infection. However, our results showed that there was no significant correlation $(p>0.05)$ with the allele and genotype frequency distribution for the ACKR1 between HCV-infected patients and the control group. Lettow et al. (24) also observed a similar result in Caucasians - the allele and genotype frequency distribution for ACKR1 (rs12075) did not differ between the control group and HCV-infected patients. Thus, we demonstrate that ACKR1 polymorphism (rs12075) does not affect susceptibility to HCV. It is probable that ACKR1 on erythrocyte membranes cannot interact with $\mathrm{HCV}$, so ACKR1 polymorphism is not associated with $\mathrm{HCV}$ susceptibility.

ACKR1 represents an atypical chemokine receptor that can bind promiscuously to various chemokines belonging to the $\mathrm{CC}$ and $\mathrm{CXC}$ families (25). In $\mathrm{HCV}$ infection, the most prominent chemokines are the $\mathrm{CC}$ and $\mathrm{CXC}$ families, and they are highly expressed (26). Studies have shown that the $\mathrm{CC}$ and $\mathrm{CXC}$ families are associated with liver injury (27). Moreover, the $\mathrm{CC}$ and $\mathrm{CXC}$ families can recruit various leukocyte subsets into the liver during the progression of HCV infection (28). Recent studies have found that ACKR1 polymorphism is associated with serum levels of CCL2 belonging to the CC family (29,30). Based on the above findings, in further studies, we will focus on whether there is a correlation between ACKR1 polymorphism and liver fibrosis progression associated with $\mathrm{HCV}$ infection.

In conclusion, our study indicates that ACKR1 polymorphism (rs12075) does not affect susceptibility to HCV and is not a risk factor for $\mathrm{HCV}$ infection.

\section{Acknowledgements}

We would like to thank Miss Nan Ding for her help in collecting samples.

Financial Disclosure: No financial disclosure was declared by the authors.

Conflict of Interest: No conflict of interest was declared by the authors.

\section{REFERENCES}

1. Williams R. Global challenges in liver disease. Hepatology 2006;44:521-6.

2. Shepard CW, Finelli L, Alter MJ. Global epidemiology of hepatitis C virus infection. Lancet Infect Dis 2005;5:558-67.

3. Bowen DG, Walker CM. Adaptive immune responses in acute and chronic hepatitis C virus infection. Nature 2005;436:946-52.

4. Mohd Hanafiah K, Groeger J, Flaxman AD, Wiersma ST. Global epidemiology of hepatitis $\mathrm{C}$ virus infection: new estimates of age-specific antibody to HCV seroprevalence. Hepatology 2013;57:1333-42.

5. Chen YS, Li L, Cui FQ, Xing WG, Wang L, Jia ZY, et al. A seroepidemiological study on hepatitis $\mathrm{C}$ in China. Zhonghua Liu Xing Bing Xue Za Zhi 2011;32:888-91.

6. Davis MB, Walens A, Hire R, Mumin K, Brown AM, Ford D, et al. Distinct Transcript Isoforms of the Atypical Chemokine Receptor 1 (ACKR1) / Duffy Antigen Receptor for Chemokines (DARC) Gene Are Expressed in Lymphoblasts and Altered Isoform Levels Are Associated with Genetic Ancestry and the Duffy-Null Allele. PloS one 2015;10:e0140098.

7. Grimberg BT, Udomsangpetch R, Xainli J, McHenry A, Panichakul T, Sattabongkot J, et al. Plasmodium vivax invasion of human erythrocytes inhibited by antibodies directed against the Duffy binding protein. PLoS Med 2007;4:e337.

8. Cotorruelo C, Biondi C, Racca L, Borras SG, Racca A. Duffy genotyping facilitates transfusion therapy. Clin Exp Med 2009;9:249-51.

9. de Carvalho GB. Duffy Blood Group System and the malaria adaptation process in humans. Rev Bras Hematol Hemoter 2011;33:55-64.

10. Iwamoto S, Li J, Sugimoto N, Okuda H, Kajii E. Characterization of the Duffy gene promoter: evidence for tissue-specific abolishment of expression in Fy(a-b-) of black individuals. Biochem Biophys Res Commun 1996;222:852-9.

11. Howes RE, Patil AP, Piel FB, Nyangiri OA, Kabaria CW, Gething PW, et al. The global distribution of the Duffy blood group. Nat Commun 2011;2:266. 
12. Neote K, Mak JY, Kolakowski LF Jr, Schall TJ. Functional and biochemical analysis of the cloned Duffy antigen: identity with the red blood cell chemokine receptor. Blood 1994;84:44-52.

13. Darbonne WC, Rice GC, Mohler MA, Apple T, Hebert CA, Valente AJ, et al. Red blood cells are a sink for interleukin 8, a leukocyte chemotaxin. J Clin Invest 1991;88:1362-9.

14. King CL, Adams JH, Xianli J, Grimberg BT, McHenry AM, Greenberg $\mathrm{LJ}$, et al. Fy(a)/Fy(b) antigen polymorphism in human erythrocyte Duffy antigen affects susceptibility to Plasmodium vivax malaria. Proc Natl Acad Sci USA 2011;108:20113-8.

15. Sippert EA, de Oliveira e Silva C, Visentainer JE, Sell AM. Association of duffy blood group gene polymorphisms with IL8 gene in chronic periodontitis. PloS one 2013;8:e83286.

16. Yang C, Yu KD, Xu WH, Chen AX, Fan L, Ou ZL, et al. Effect of genetic variants in two chemokine decoy receptor genes, DARC and CCBP2, on metastatic potential of breast cancer. PloS one 2013;8:e78901.

17. Kanto T, Hayashi N, Takehara T, Katayama K, Kato M, Akiyama M, et al. Low expression of erythrocyte complement receptor type 1 in chronic hepatitis C patients. J Med Virol 1996;50:126-34.

18. Miyaike J, Iwasaki Y, Takahashi A, Shimomura H, Taniguchi H, Koide N, et al. Regulation of circulating immune complexes by complement receptor type 1 on erythrocytes in chronic viral liver diseases. Gut 2002;51:591-6.

19. Ohi H, Tamano M, Okada N. Low CR1 (C3b receptor) level on erythrocytes is associated with poor prognosis in hemodialysis patients. Nephron Clin Pract 2008;108:23-7.

20. He W, Neil S, Kulkarni H, Wright E, Agan BK, Marconi VC, et al. Duffy antigen receptor for chemokines mediates trans-infection of HIV-1 from red blood cells to target cells and affects HIV-AIDS susceptibility. Cell Host Microbe 2008;4:52-62.

21. Ramsuran V, Kulkarni H, He W, Mlisana K, Wright EJ, Werner L, et al. Duffy-null-associated low neutrophil counts influence HIV-1 susceptibility in high-risk South African black women. Clin Infect Dis 2011;52:1248-56.
22. Cutbush M, Mollinson PL, Parkin DM. A new human blood group. Nature 1950;165:188-90.

23. Neote K, Darbonne W, Ogez J, Horuk R, Schall TJ. Identification of a promiscuous inflammatory peptide receptor on the surface of red blood cells. J Biol Chem 1993;268:12247-9.

24. Lettow I, Berres ML, Schmitz P, Müller T, Berg T, Neumann UP, et al. A Duffy antigen receptor for chemokines (DARC) polymorphism that determines pro-fibrotic chemokine serum concentrations is not directly associated with severity of hepatitis C infection. Hum Immunol 2011;72:273-7.

25. Kashiwazaki M, Tanaka T, Kanda H, Ebisuno Y, Izawa D, Fukuma N, et al. A high endothelial venule-expressing promiscuous chemokine receptor DARC can bind inflammatory, but not lymphoid, chemokines and is dispensable for lymphocyte homing under physiological conditions. Int Immunol 2003;15:1219-27.

26. Berres ML, Trautwein C, Schmeding M, Eurich D, Tacke F, Bahra M, et al. Serum chemokine CXC ligand 10 (CXCL10) predicts fibrosis progression after liver transplantation for hepatitis $\mathrm{C}$ infection. Hepatology 2011;53:596-603.

27. Palmer C, Corpuz T, Guirguis M, O'Toole S, Yan K, Bu Y, et al. The effect of obesity on intrahepatic cytokine and chemokine expression in chronic hepatitis C infection. Gut 2010;59:397-404.

28. Heydtmann M, Adams DH. Chemokines in the immunopathogenesis of hepatitis C infection. Hepatology 2009;49:676-88.

29. Comerford I, Milasta S, Morrow V, Milligan G, Nibbs R. The chemokine receptor CCX-CKR mediates effective scavenging of CCL19 in vitro. Eur J Immunol 2006;36:1904-16.

30. Schnabel RB, Baumert J, Barbalic M, Dupuis J, Ellinor PT, Durda P, et al. Duffy antigen receptor for chemokines (Darc) polymorphism regulates circulating concentrations of monocyte chemoattractant protein-1 and other inflammatory mediators. Blood 2010;115:5289-99. 